\title{
Performance Evaluation of Photovoltaic Models Based on a Solar Model Tester
}

\author{
Salih Mohammed Salih \\ Electrical Engineering Department, University of Anbar, Ramadi, Iraq \\ dr_salih_moh@ieee.org \\ Firas Fadhil Salih \\ Electrical Engineering Department, University of Anbar, Ramadi, Iraq \\ firas_alrawi2003@yahoo.com \\ Mustafa Lateef Hasan \\ Electrical Engineering Department, University of Anbar, Ramadi, Iraq \\ mustaffa_900@yahoo.com \\ Mustafa Yaseen Bedaiawi \\ Electrical Engineering Department, University of Anbar, Ramadi, Iraq \\ mu_288@yahoo.com
}

\begin{abstract}
The performances of $130 \mathrm{~W}$ (Solara PV) and $100 \mathrm{~W}$ (Sunworth PV) solar modules are evaluated using a single diode equivalent circuit. The equivalent circuit is able to simulate both the $I-V$ and $P-V$ characteristic curves, and is used to study the effect of the operating temperature, diode ideality factor, series resistance, and solar irradiance level on the model performance. The results of the PV characteristics curves are compared with the parameters from the manufacturing companies for each model. Afterwards, the Solara PV model is tested under different irradiance levels. The relationship between the model power versus its current under different irradiance levels is plotted, such that if the solar power meter (pyrheliometer) does not exist, the irradiance-current $(G-I)$ curve can be used to measure solar radiation power without using the solar power meter. The measurement is achieved by moving the solar panel by a certain angle toward the solar radiation, and then measuring the corresponding current.
\end{abstract}

Index Terms - Irradiance, Solara PV, Sunworth PV, $P-$ $V, I-V$, Solar Model Tester

\section{Introduction}

The worldwide photovoltaic (PV) market has grown by an average of $30 \%$ annually for the past 15 years, an increase that has improved economies of scale for manufacturers ${ }^{[1]}$. As a result, the cost of electricity generated from PV modules has decreased significantly, from more than 45 cents per kilowatt hour $(\mathrm{kWh})$ in 1990 to about 23 cents per $\mathrm{kWh}$ in $2006^{[2]}$. In 2006 and 2007, a shortage of silicon (a primary component of crystalline silicon PV systems) temporarily increased the
PV module costs, but prices decreased once again between 2008 and 2011 when silicon plants under construction became complete ${ }^{[3]}$.

Historically, two time-of-day dependent factors complicated the characterization of PV modules and array performances, namely, changes in the solar spectrum over the day and optical effects in the module that varied with the solar angle-of-incidence. Ref. [4] describes straightforward methods for directly measuring the effects of these two factors, and provides the measured results for commercial modules as well as for typical solar irradiance sensors (pyranometers). The empirical relationships obtained from the measurements can be used to improve the methods used for system design, verification of performance after installation, and diagnostic monitoring of performance during operation.

One of the most important parameters for PV plant performance assessment is solar irradiance. The horizontal irradiance is measured in most PV sites. In fact, measuring the in-plane irradiance for PV plant performance assessment is required. The direct irradiance is also important for installing automatic solar trackers and obtains the maximum power point from the installed power plants. However, sporadic cloud movements and changes cause inaccurate measurements.

In [5], a new method of calculating in-plane irradiance using one-minute local solar irradiance is proposed. The use of this method provides better results than another method where horizontal irradiance is used. In-plane irradiance with various angles can also be calculated with accuracy for the surrounding area using local solar irradiance and PV site one-minute horizontal irradiance. 
In [6], a mathematical model for PV models is analyzed. A one-diode equivalent circuit was employed to investigate the $I-V$ and $P-V$ characteristics of typical 54 and $100 \mathrm{~W}$ solar models. The models were used to study different parameter variations that can affect the PV array performance, including the operating temperature and solar irradiance level.

In this paper, the performance of solar modules (130W (Solara PV) and $100 \mathrm{~W}$ (Sunworth PV)) under different conditions (i.e., temperature, series resistance, solar irradiance, and diode ideality factor) is analyzed by a diode equivalent circuit. Next, a solar model tester is used to measure the values of currents under different irradiance $(G)$ levels, and the relationship between the irradiance and current $(G-I)$ is plotted. Hence, this curve can be used to calculate the irradiance values at any time without a pyrheliometer. This calculation can be achieved by simply moving the solar model at certain angles to get the current values and the corresponding values of $\mathrm{G}$ in the $G-I$ curve.

The remainder of this paper is organized as follows: Section 2 gives the simulator types. Section 3 gives the solar simulator requirements. Section 4 describes the solar cell simulation model. Section 5 presents the simulation results based on solar cell simulation model. Section 6 gives the practical results based on solar model tester. Conclusions are given in the final section.

\section{Simulator Types}

There are three types of simulators as follows:

a) Constant light

- Heat load, cooling, and high-power consumption

b) Pulsed light

- No heating of sample

- Fast measurement and no temperature leveling

c) Pulsed light and decaying

- Can measure easily at different irradiation levels

- Measurement of series resistance

- High peak irradiance easily reached

The measurement principle of a PV system is shown in Fig. 1.

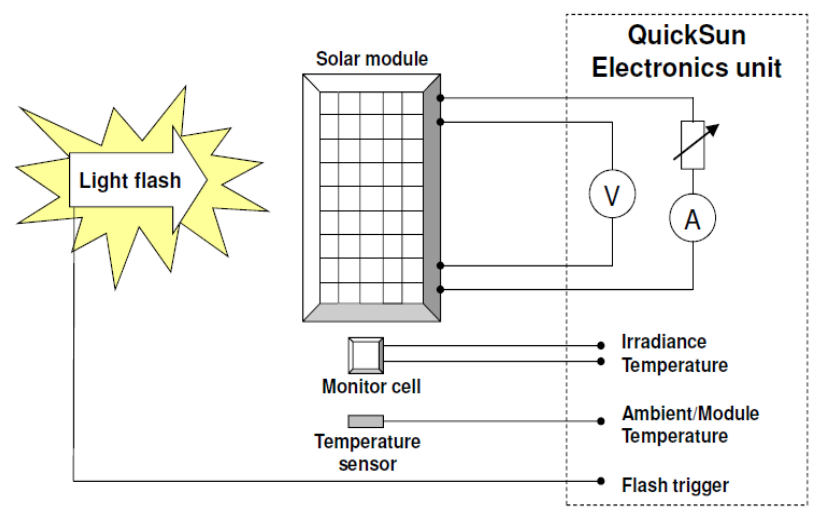

Fig. 1: Measurement principle of the PV model (QuickSun NAPS Co.)

\section{Solar Simulator Requirements}

The performance requirements for a solar simulator are as follows:

a) Standard IEC 904-9 describes the requirements for solar simulators.

b) The three key aspects of solar simulator performance are

- Positional non-uniformity

- Spectral match

- Temporal instability (short- and long-term)

c) The previous parameters can be applied to all PV technologies, but using spectral match criteria designed for $\mathrm{c}-\mathrm{Si}$

d) For performance measurements, a class CBA simulator is the minimum

- $(\mathrm{C}=$ Spectrum, $\mathrm{B}=$ Non-uniformity, $\mathrm{A}=\mathrm{STI})$

e) LTI specification for irradiance exposure tests. The standard parameters are given in Table 1.

Table 1 Standard parameters for solar cell classes

\begin{tabular}{|l|c|c|c|}
\hline \multicolumn{1}{|c|}{ Characteristic } & Class A & Class B & Class C \\
\hline $\begin{array}{l}\text { Spectral match (ratio of the } \\
\text { actual percentage of total } \\
\text { irradiance to the required } \\
\text { percentage specified for each } \\
\text { wavelength range) }\end{array}$ & $\begin{array}{c}0.75- \\
1.25\end{array}$ & $0.6-1.25$ & $0.4-2.0$ \\
\hline No-uniformity of irradiance & $< \pm 2 \%$ & $< \pm 5 \%$ & $< \pm 10 \%$ \\
\hline $\begin{array}{l}\text { Temporal instability, short } \\
\text { term, STI }\end{array}$ & $< \pm 0.5 \%$ & $< \pm 2 \%$ & $< \pm 10 \%$ \\
\hline $\begin{array}{l}\text { Temporal instability, long } \\
\text { term, LTI }\end{array}$ & $< \pm 2 \%$ & $< \pm 5 \%$ & $< \pm 10 \%$ \\
\hline
\end{tabular}

\section{Modeling the Solar Cell}

The simplest equivalent circuit of a solar cell is a current source parallel with a diode and series resistance, as shown in Figure 2. The output of the current source is directly proportional to the light falling on the cell (photocurrent $\mathrm{I}_{\mathrm{L}}$ ). During darkness, the solar cell is not an active device; it works as a diode, i.e., a p-n junction. It produces neither a current nor a voltage. However, if it is connected to an external supply (large voltage), it generates a current $I_{d}$ called diode (D) current or dark current. The diode determines the $I-V$ characteristics of the cell ${ }^{[6,7]}$.

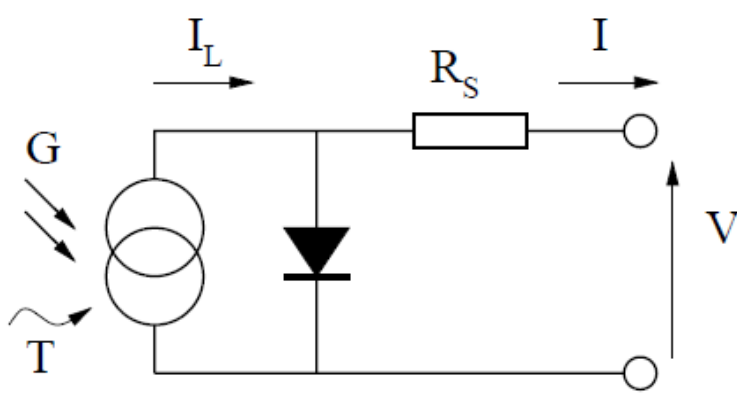

Fig. 2: Solar cell with single-diode and series resistance. 
The $I-V$ characteristics of the solar cell with singlediode and series resistance are given by the following steps:

$$
I=I_{L}-I_{0}\left(e^{\frac{q\left(V+I^{*} R s\right)}{n k T}}-1\right)
$$

For the same irradiance and $\mathrm{p}-\mathrm{n}$ junction temperature conditions, the inclusion of a series resistance in the model implies the use of a recurrent equation to determine the output current as a function of the terminal voltage. A simple iterative technique initially attempted only converging positive currents. The Newton-Raphson method converges more rapidly and can be used for both positive and negative currents ${ }^{[6-8]}$. The short circuit current $I_{\mathrm{sc}}$ is given by:

$$
I_{s c}=I=I_{L}-I_{0}\left(e^{\frac{q(R s+I s c)}{n k T}}-1\right) \quad \text { for } V=0
$$

and when the series resistance is small and negligible

$$
I_{s c}=I=I_{L}
$$

Normally, the series resistance is small and negligible in computing Eq. (2). Hence, Eq. (3) is used as a good approximation of Eq. (2). The open circuit voltage $V_{\mathrm{oc}}$ is given by

$$
V=V_{o c}=\frac{n k T}{q} \ln \left(1+\frac{I_{s c}}{I_{0}}\right) \quad \text { for } I=0
$$

The output power is given by

$$
P=V\left[I_{s c}-I_{0}\left(e^{\frac{q(v+R s)}{n k T}}-1\right)\right]
$$

Solar cells consist of a p-n junction fabricated in a thin wafer or layer of semiconductor. In the dark, the $I-$ $V$ output characteristic of a solar cell has an exponential characteristic similar to that of a diode. When exposed to light, photons with energy greater than the band gap energy of the semiconductor are absorbed and create an electron-hole pair. These carriers are swept apart under the influence of the internal electric fields of the $p-n$ junction, and create a current proportional to the incident radiation. When the cell is short circuited, this current flows in the external circuit; when open-circuited, this current is shunted internally by the intrinsic $p-n$ junction diode. Therefore, the characteristics of this diode set the open circuit voltage characteristics of the cell ${ }^{[9]}$

Solara PV and Sunworth PV modules are chosen for modeling because of their suitability to the traditional applications of a PV system. The Solara PV and Sunworth PV modules provide nominal maximum power, and both have 36 series-connected polycrystalline silicon cells. The key specifications are shown in Table (2). The model parameters are evaluated during program execution using the next equations. The program can calculate the current $I$ using the typical electrical parameters of the module $\left(I_{\mathrm{sc}}\right.$ and $\left.V_{\mathrm{oc}}\right)$, variable voltage, irradiation $(G)$, series resistance $\left(R_{\mathrm{s}}\right)$, diode ideality factor $(n)$, and temperature $(T)$.

The program considers the series resistance in the model. This resistance makes the solution for the current I (Eq.(1)) a non-linear problem that can be solved by numerical methods.

$$
\begin{aligned}
& K_{0}=\frac{I_{s c-} T_{1}-I_{s c-} T_{1}}{T_{2}-T_{1}} \\
& I_{L-} T_{1}=I_{s c-} T_{1} * G \\
& I_{L}=I_{L-} T_{1}+K_{0} \times\left(\text { Tak }-T_{1}\right) \\
& I_{0-} T_{1}=\frac{I_{s c-} T_{1}}{e^{\frac{q \times V_{o c} T_{1}}{n k T_{1}}}-1}
\end{aligned}
$$

$I_{0}=I_{0-} T_{1} *\left(\frac{T a k}{T_{1}}\right)^{\left(\frac{3}{n}\right)} * e^{\frac{-q^{*} V_{g}}{n k} *\left(\frac{1}{T a k}-\frac{1}{T_{1}}\right)}$

$X v=\frac{I_{0-} T_{1} * q}{n k T_{1}} * e^{\frac{q^{*} V_{o c} T_{1}}{n k T_{1}}}$

$\frac{d V}{d I-V o c}=\frac{-1.15}{2 * N s}$

$$
R s=\frac{-d v}{d I-V o c}-\frac{1}{X v}
$$

$$
V t_{-} T a=\frac{n k T a k}{q}
$$

$$
I a=I a-\frac{\left(I_{L}-I a-I_{0} *\left(e^{\frac{V c+I a^{*} R s}{V t+T a}}-1\right)\right)}{-1-\left(I_{0} *\left(e^{\frac{V c+I a^{*} R s}{V t t_{-} T a}}-1\right) * \frac{R s}{V t_{-} T a}\right)}
$$

\section{Simulation Results}

In this section, the $I-V$ and $P-V$ characteristics of Solara PV and Sunworth PV modules with variables $G$, $R_{\mathrm{s}}, n$, and $T$ are calculated using Matlab software. 
Table 2 Specifications of the Solara PV and Sunworth PV models

\begin{tabular}{|c|c|c|}
\hline Parameter & $\begin{array}{c}\text { Solara } \\
\text { (Germany) }\end{array}$ & $\begin{array}{c}\text { Sunworth } \\
\text { (China) }\end{array}$ \\
\hline$V_{\max }(\mathrm{V})$ & 17.8 & 18 \\
\hline$I_{\max }(\mathrm{A})$ & 7.3 & 5.56 \\
\hline$V_{\text {oc }}(\mathrm{V})$ & 21.7 & 21.6 \\
\hline$I_{\mathrm{sc}}(\mathrm{A})$ & 8.18 & 5.88 \\
\hline$P_{\text {out }}(\mathrm{W})$ & 130 & 100 \\
\hline
\end{tabular}

Note: The data are based on measurements made in a solar simulator at Standard Test Conditions (STC), which are:

- Illumination of $1 \mathrm{~kW} / \mathrm{m}^{2}$ (1 sun) at a spectral distribution of AM 1.5;

- Cell temperature of $25^{\circ} \mathrm{C}$ or as otherwise specified (on curves).

\section{A. Irradiance}

A PV system is based on the ability of certain materials to convert the radiant energy of the sun into electrical energy. The total amount of solar energy that lights a given area is known as the irradiance $(G)$, which is measured in watts per square meter $\left(\mathrm{W} / \mathrm{m}^{2}\right)$. The instantaneous values are normally averaged over a period; thus, irradiance is usually mentioned in terms of total irradiance per hour, day, or month.

To show the effect of irradiance on the performance of a module, the temperature is kept fixed at $25{ }^{\circ} \mathrm{C}$, the diode ideality factor is kept at $n=1.2$, and the values of irradiance are changed to different values $(0.5,0.75,1$, and 1.2) sun, where $\left(1\right.$ sun $\left.=1000 \mathrm{~W} / \mathrm{m}^{2}\right)$. The variation of the current-voltage characteristics with irradiance is shown in Figures 3 and 4. The figures show that the maximum current when $G=1.2$ is about 9.8 A for Solara PV module and 7.1 A for Sunworth PV. The minimum current when $G=0.5$ is about 4.1 A for Solara PV module and 2.9 A for Sunworth PV. Irradiance clearly has a major effect on the short circuit current, and the relationship of irradiance with the short circuit current is indeed a linear one. The $P-V$ characteristic is shown in Figures 5 and 6 . The maximum power occurs when $V=15.4 \mathrm{~V}(G=1.2)$ for Solara PV module, and the maximum power occurs when $V=16.5 \mathrm{~V}(G=1.2)$ for Sunworth PV. The maximum power occurs when $V$ $=16.4 \mathrm{~V}(G=0.5)$ for Solara PV module and at $V=16.8$ $\mathrm{V}(G=0.5)$ for Sunworth PV.

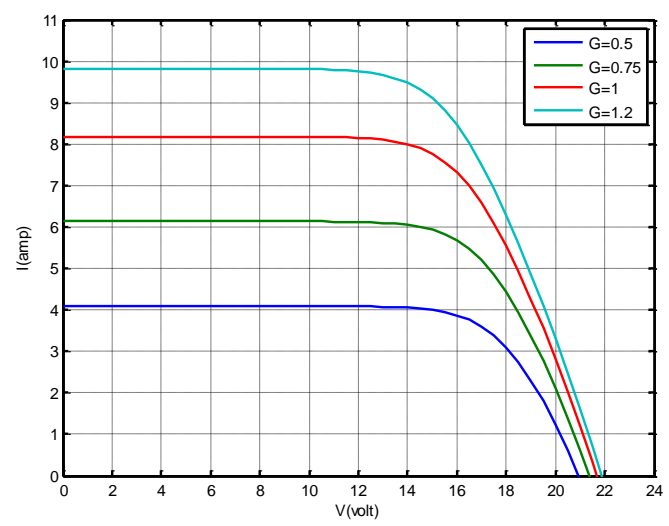

Fig. 3: $I-V$ characteristic curve with irradiance variation (Solara PV)

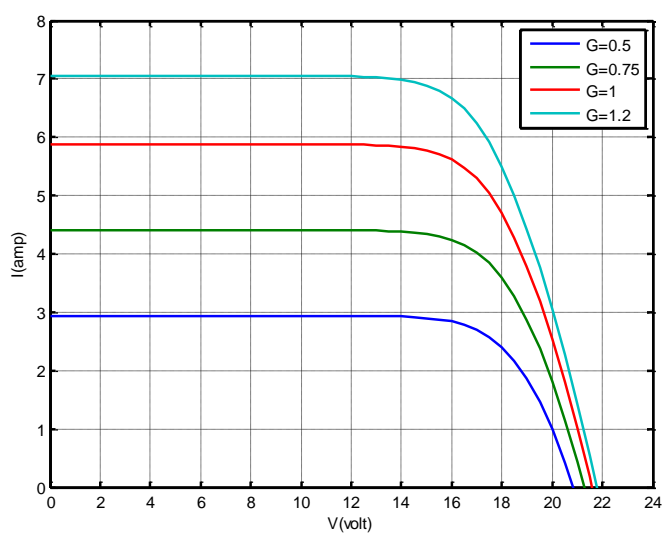

Fig. 4: $I-V$ characteristic curve with irradiance variation (Sunworth PV)

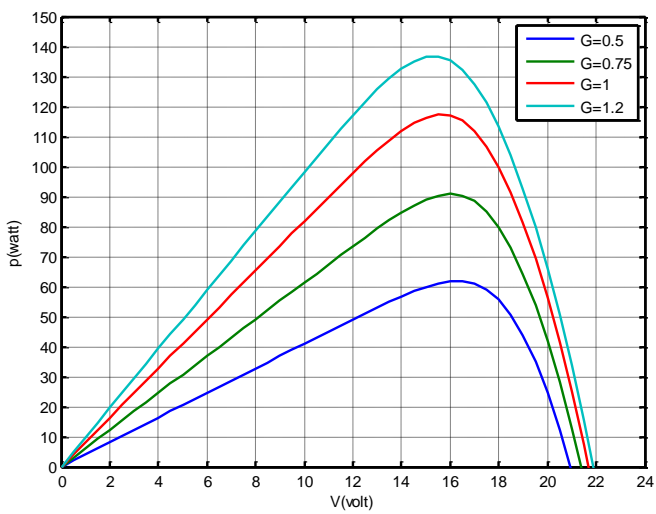

Fig. 5: $P-V$ characteristic curve with irradiance variation (Solara PV)

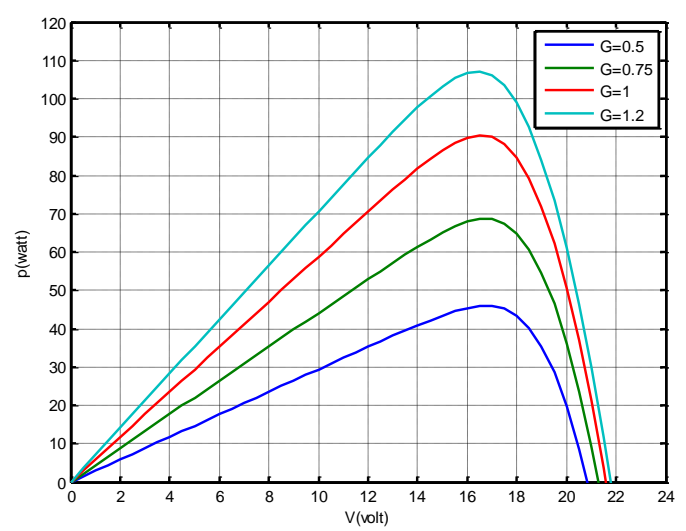

Fig. 6: $P-V$ characteristic curve with irradiance variation (Sunworth PV)

\section{B. Diode Ideality Factor}

The calculations are based on a silicon module of 36 cells at different diode ideality factor values. As the diode ideality factor increases, a longer bend in the knee of the $I-V$ curve occurs and the maximum power point on the $I-V$ curve begins to decrease. The diode ideality factor affects the diode saturation current $\left(I_{\mathrm{o}}\right)$, as seen in Eq. (11). The range of the ideality factor is from 1 to 2 , where $n=1$ is an ideal diode and $n=2$ is a non-ideal diode. As the ideality factor approaches 2 , more defects are introduced into the material and more recombination 
(electron/hole elimination) occurs ${ }^{[10]}$. The materials with diode ideality factors greater than 2 are multijunction cells. These types of cells have multiple $p-n$ junctions layered on top of one another instead of a single p-n junction. This increases the value of the ideality factor.

To show the effect of the diode ideality factor on the performance of a module, the temperature is fixed at $25^{\circ} \mathrm{C}$, the irradiance is fixed at $G=1$ sun, and the diode ideality factors are varied $(1,1.3,1.6$, and 2$)$. The $I-V$ characteristic curves for both models are shown in Figures 7 and 8 . The current increases as the diode ideality factor $(n)$ decreases for both models. The maximum current for the Solara PV is $8.18 \mathrm{~A}$ and that for the Sunworth PV is 5.88 A. Figure 7 shows that in the Solara model, when the charging voltage lies between 12 and $16 \mathrm{~V}$, the maximum current (at $n=1$ ) decreases from $8.15 \mathrm{~A}$ to $7.4 \mathrm{~A}$, and the maximum current decreases from 5.85 A to 5.7 A in Sunworth PV. This means that the Solara model $(130 \mathrm{~W})$ has a dropping current of $0.75 \mathrm{~A}$, whereas the Sunworth model $(100 \mathrm{~W})$ has a dropping current of $0.15 \mathrm{~A}$. Thus, the first model is more suitable for charging batteries that can accept fast-charging current, whereas the second model is suitable for batteries with a charging time 1/10 of the total charging current. Figures 9 and 10 show the $P-V$ characteristic curve with the diode ideality factor variation for the Solara PV and Sunworth PV models. The maximum power points for these models at different diode ideality factors are dependent on the variation of $n$. The maximum power point in Figure 9 can be obtained at $15.6 \mathrm{~V}(n=1)$, where the $\mathrm{O} / \mathrm{P}$ power ranges from 110 $\mathrm{W}$ to $120 \mathrm{~W}$ as the diode ideality factor varies from 2 to 1 . The output power at $12 \mathrm{~V}$ is about $98 \mathrm{~W}$ for $(n=1)$.

Figure 10 shows the effect of the diode ideality factor on the Sunworth $P-V$ characteristic curve. The maximum power can be obtained at $16.6 \mathrm{~V}$ instead of $15.6 \mathrm{~V}$, as in the previous model. The power ranges from $84 \mathrm{~W}$ to $92 \mathrm{~W}$ as the diode ideality factor decreases from 2 to 1 . The maximum power point is important in determining the type of batteries that can be used in the system design.

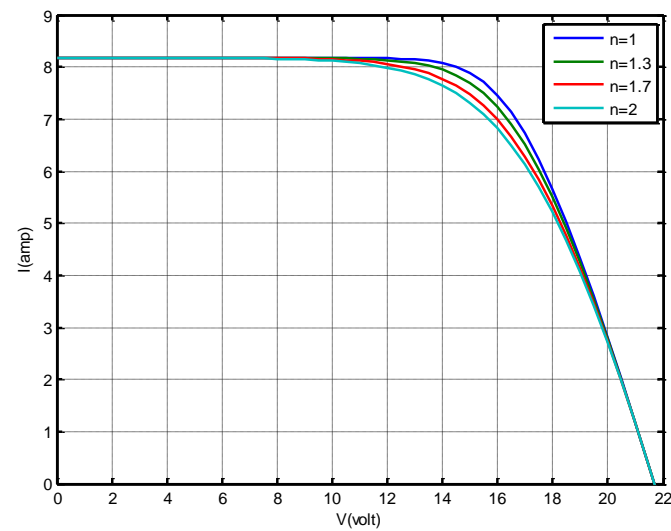

Fig. 7: $I-V$ characteristic curve with diode ideality factor variation (Solara PV)

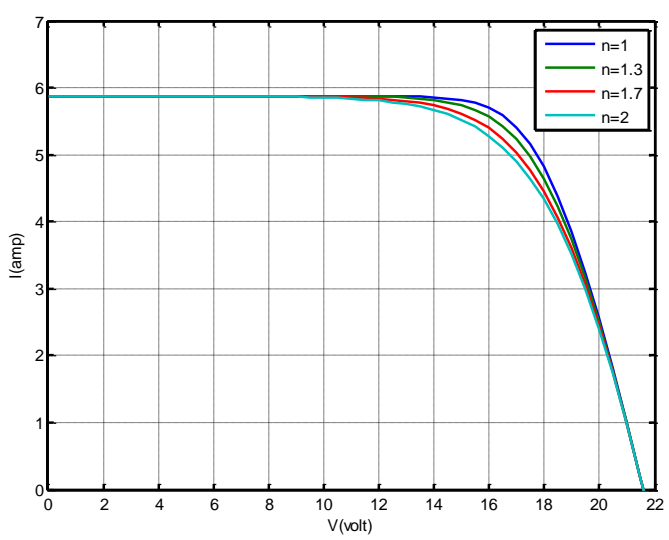

Fig. 8: $I-V$ characteristic curve with diode ideality factor variation (Sunworth PV)

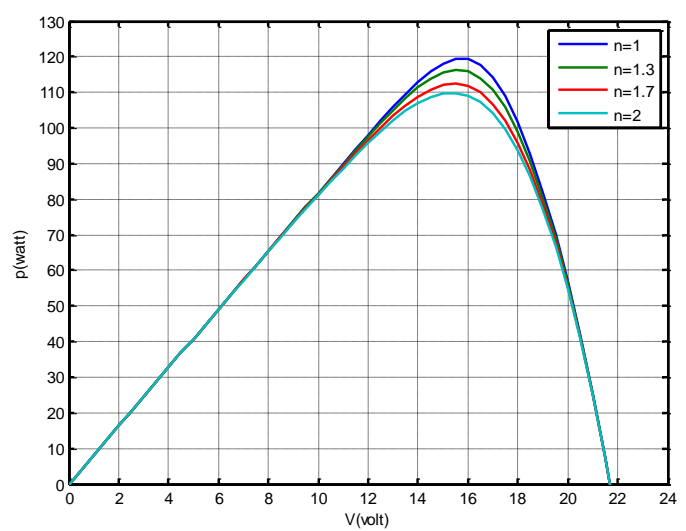

Fig. 9: $P-V$ characteristic curve with diode ideality factor variation (Solara PV)

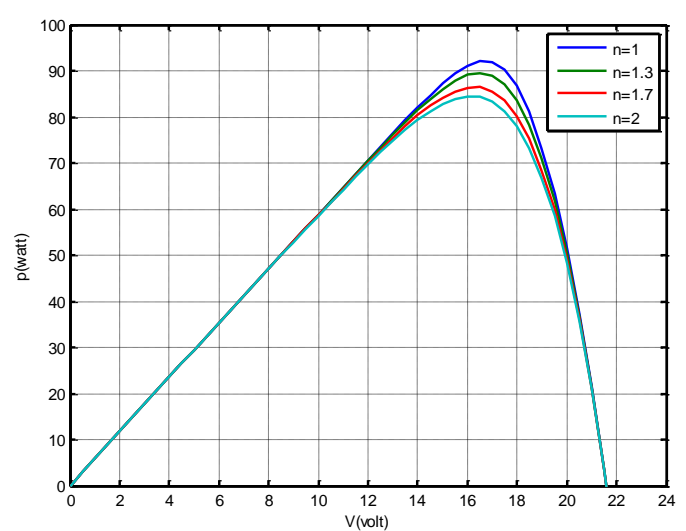

Fig. 10: $P-V$ characteristic curve with diode ideality factor variation (Sunworth PV)

\section{Temperature Effect}

The temperature of a PV module greatly affects its performance. Although the temperature is not as important as the duration and intensity of sunlight, the PV module power output is reduced at high temperatures. The temperature of a PV module also affects its efficiency. In general, the efficiency of a crystalline silicon PV module is reduced by about $0.5 \%$ for every Celsius degree increase in temperature. Varying the 
temperature does not significantly affect the current developed, but the voltage drop increases with increasing heat ${ }^{[11]}$.

The dominant effect of increased cell temperature is the linear decrease of the open circuit voltage, making the cell less efficient. The short circuit current slightly increases with increased cell temperature at constant irradiance. The voltage output from the PV array decreases but the current output increases slightly with respect to the voltage. Consequently, the power output from the PV array decreases.

The influence of the cell temperature on the $I-V$ characteristics is illustrated in Figures 11 and 12. The effect of temperature variation $\left(0,25,40\right.$, and $\left.70{ }^{\circ} \mathrm{C}\right)$ on the $I-V$ characteristics at a constant irradiance of $G=1$ sun and diode ideality factor of $n=1.2$ is shown. Figures 13 and 14 demonstrate that when temperature increases, the output power for both models decreases.

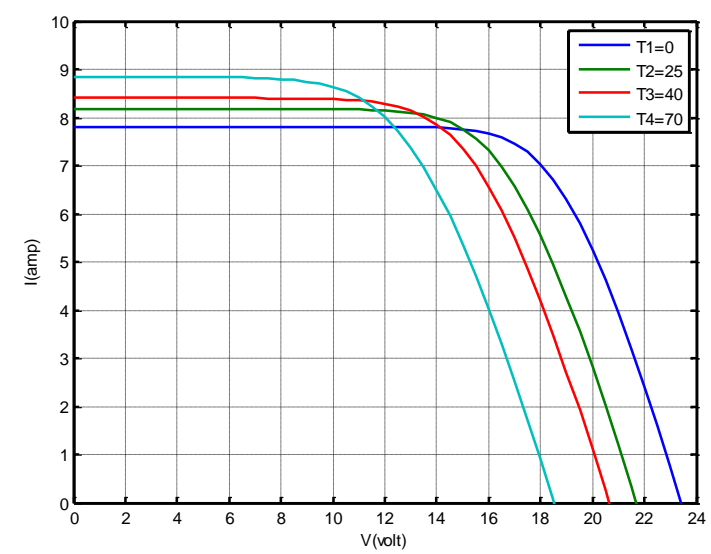

Fig. 11: $I-V$ characteristic curve with temperature variation (Solara PV)

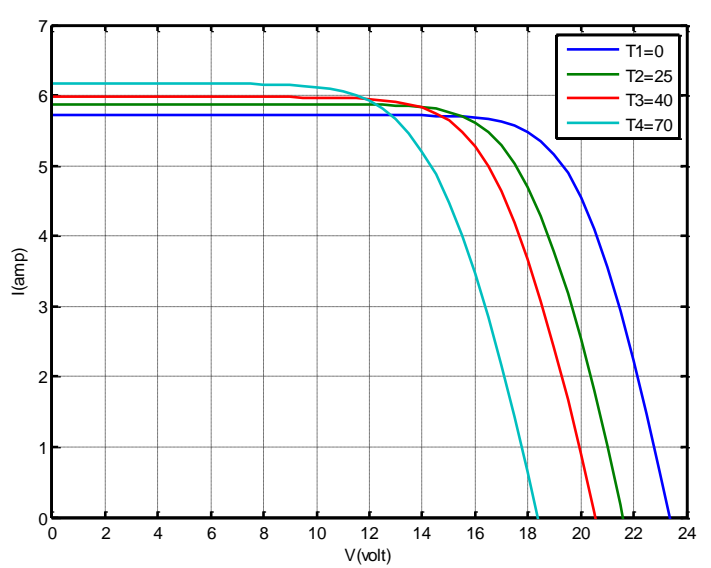

Fig. 12: $I-V$ characteristic curve with temperature variation (Sunworth PV)

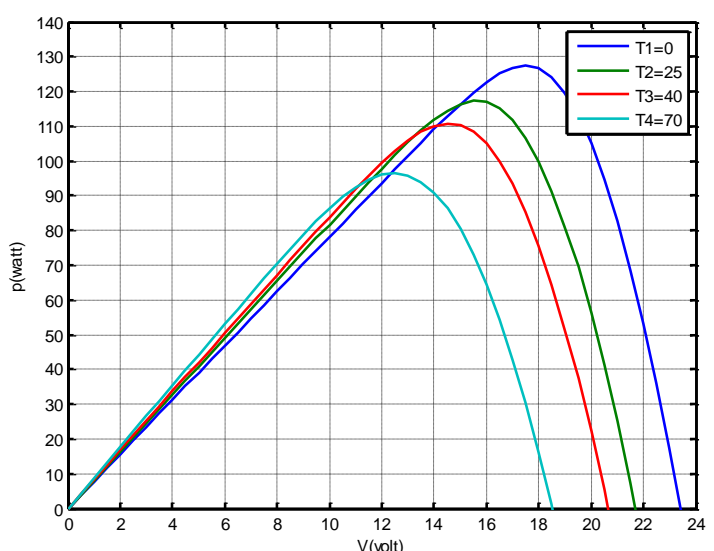

Fig. 13: $P-V$ characteristic curve with temperature variation (Solara PV)

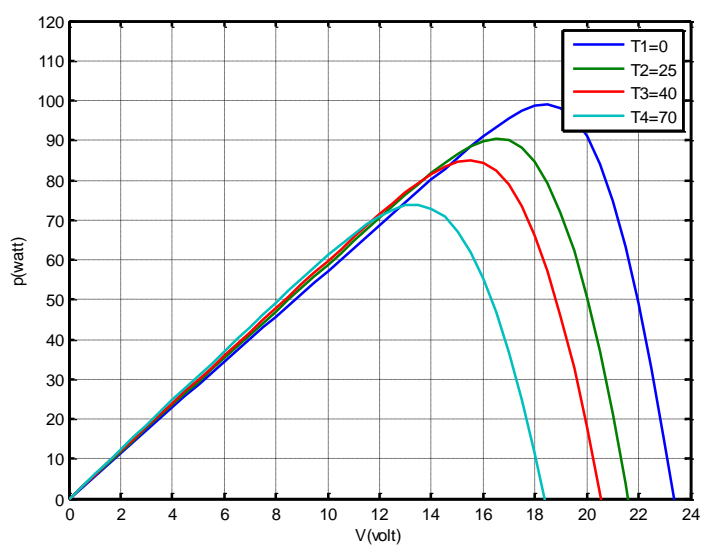

Fig. 14: $P-V$ characteristic curve with temperature variation (Sunworth PV)

\section{Internal Resistance}

The series resistance is a parasitic resistance detrimental to solar cell performance because it reduces the device power output. The series resistance $R_{\mathrm{s}}$ of a PV module represents the resistances in cell solder bonds, emitter and base region, cell metallization, cell interconnect bus bars, and junction-box terminals. The series resistance in a cell should be no more than a few tenths of milliohm for each square centimeter of illuminated cell area under a one sun condition. The series resistance also becomes more effective at highgenerated photocurrents ${ }^{[9]}$. The series resistance of a panel has a large impact on the slope of the $I-V$ curve and rearrangement in terms of $R_{\mathrm{S}}{ }^{[12]}$. Using the values obtained from the curves of Solara PV and Sunworth PV, the total panel series resistance is estimated to be $0-20$ milliohm. Figure 15 shows the effect of the series resistance on the Solara PV model $(130 \mathrm{~W})$. The maximum charging current can be obtained at $R_{\mathrm{s}}=0$. As the series resistance increases, the output charging current (and the power) decreases. Figure 16 shows the $I-V$ performance of the Sunworth model $(100 \mathrm{~W})$. Higher losses can occur at high series resistance values, which mean that the system efficiency can be increased by reducing the series resistance depending on the 
manufacturing company. From the $P-V$ characteristic curve of the Solara PV shown in Figure 17, we can obtain the internal resistance. Based on the power $130 \mathrm{~W}$, the resistance $R_{\mathrm{S}}=0.006 \mathrm{ohm}$ and the maximum power is $130 \mathrm{~W}$, which matches the exact value of the power on the nameplate of PV. At $R_{\mathrm{s}}=0.0015 \mathrm{ohm}$ for the Sunworth model, the maximum power is $100 \mathrm{~W}$. The series resistance can be measured directly by an ohmmeter device. Practical calculation reveals that $R_{\mathrm{s}} \approx$ 72 milliohm for the Solara PV module.

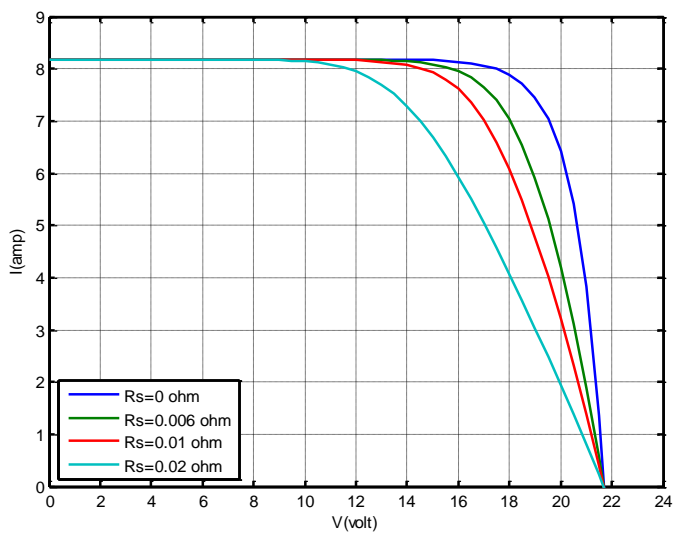

Fig. 15: $I-V$ characteristic curve with internal resistance variation (Solara PV)

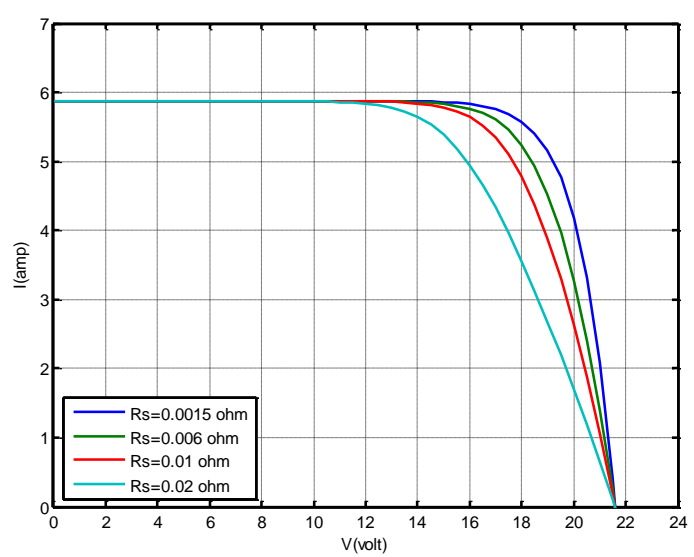

Fig. 16: $I-V$ characteristic curve with internal resistance variation (Sunworth PV)

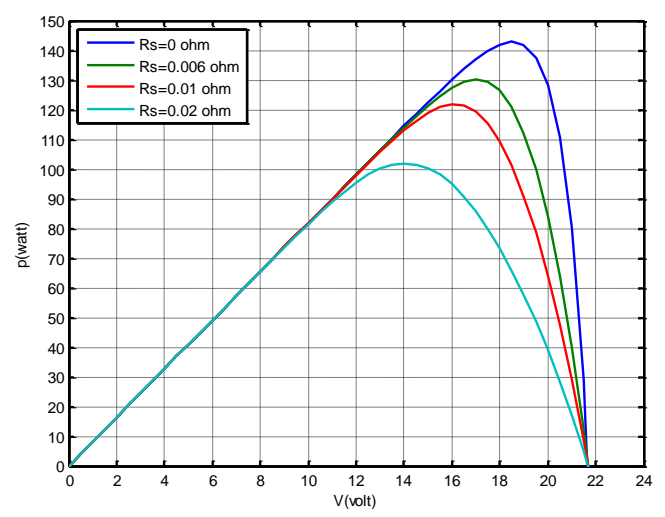

Fig. 17: $P-V$ characteristic curve with internal resistance variation (Solara PV)

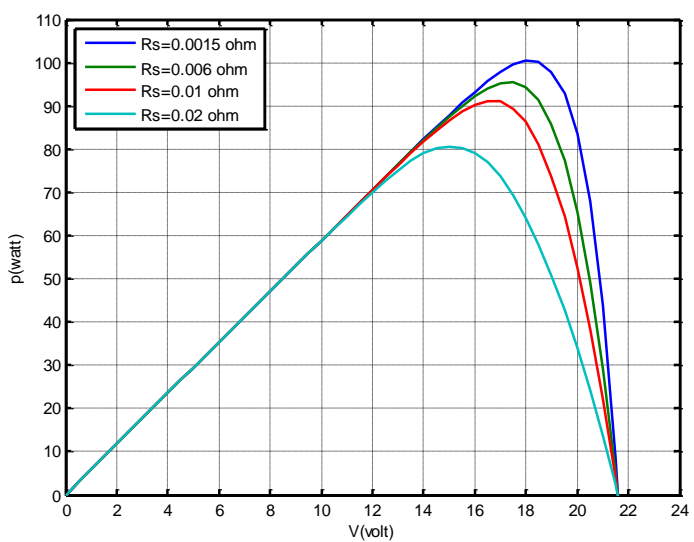

Fig. 18: $P-V$ characteristic curve with internal resistance variation (Sunworth PV)

\section{Solar Module Tester Results}

The performance of the PV module is derived from the $I-V$ and $P-V$ characteristic curves measured under STCs $\left(T=25{ }^{\circ} \mathrm{C}, G=1000 \mathrm{~W} / \mathrm{m}^{2}\right.$, and AM $\left.=1.5\right)$. The results can be obtained directly from the solar model tester, and can also set the values of solar irradiance from the software of the model tester. We test the Solara PV model to plot the $G-I$ curve. The Solara PV model can then be used to measure the solar irradiance in the absence of a solar power meter.

Figure 19 shows the $I-V$ and $P-V$ characteristic curves and the key specifications $\left(I_{\mathrm{sc}}, V_{\mathrm{oc}}, P_{\mathrm{m}}, I_{\mathrm{pm}}, V_{\mathrm{pm}}\right.$, and FF) for the Solara PV module.

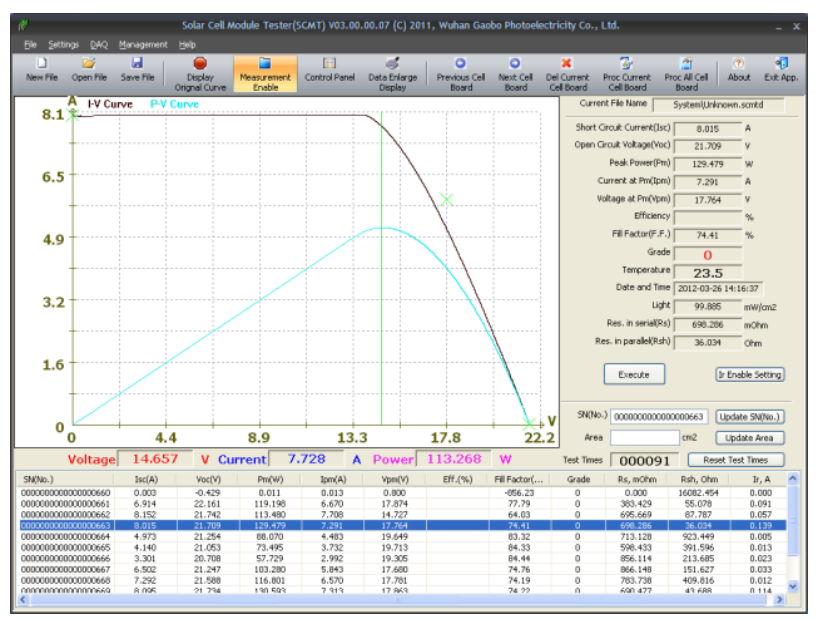

Fig. 19: $I-V$ and $P-V$ characteristics of (Solara PV) model at 1000 $\mathrm{W} / \mathrm{m}^{2}$

\section{A. Characteristic Curves at Variable Irradiance}

During the real calculation of PV model power under the sun radiation effect, the value of solar power irradiance $\left(\mathrm{W} / \mathrm{m}^{2}\right)$ where the calculations are performed must be determined because solar power radiation varies from time to time. At the same time, the tilt of the PV panel is important in obtaining the maximum power, and the values in the nameplate at the back of each panel are measured at STCs in the manufacturing companies (i.e. 
$\left.V_{\mathrm{oc}}, I_{\mathrm{sc}}, V_{\mathrm{mp}}, I_{\mathrm{mp}}, \mathrm{T}=25{ }^{\circ} \mathrm{C}, G=1000 \mathrm{~W} / \mathrm{m}^{2}\right)$. The standard solar irradiance $\left(1000 \mathrm{~W} / \mathrm{m}^{2}\right)$ can be obtained practically by moving the solar panel left-right-up-down (tilt angle) until the $V_{\text {oc }}$ and $I_{\text {sc }}$ read by the meter device match the values in the nameplate. However, if the values are different, the solar irradiance is less or more than $1000 \mathrm{~W} / \mathrm{m}^{2}$. This property can be exploited to plot the relation between the irradiance $(G)$ and short circuit current $\left(I_{\mathrm{sc}}\right)$. The existing solar model simulator can be used to function as such by varying the irradiance on the solar model (for example, the Solara $130 \mathrm{~W}$ model), and we obtain the corresponding $I_{\mathrm{sc}}$ and $V_{\mathrm{oc}}$. We repeat this step at different values of solar power radiation until the relation between the $G-I$ and $\mathrm{G}-\mathrm{V}$ curves can be plotted. The $G-I$ curve can be used for such a model to calculate the solar radiation power at any location using the tested PV model (Solara $130 \mathrm{~W}$ ) instead of using a pyrheliometer, which may not exist in most places. This model can be also used to install the solar cell systems at required angles by simply moving it according to the $G-$ $I$ curve. Figure 20 shows the $I-V$ and $P-V$ curves for the Solara PV model at an irradiance of $373 \mathrm{~W} / \mathrm{m}^{2}$. Based on this figure, $I_{\mathrm{sc}}=3.301 \mathrm{~A}$ and $V_{\mathrm{oc}}=20.708 \mathrm{~V}$. The other values of $I_{\mathrm{sc}}$ and $V_{\mathrm{oc}}$ for different values of solar irradiance are shown in Figures 21 to 26 . The summarized values of $G, I_{\mathrm{sc}}$, and $V_{\mathrm{oc}}$ are given in Table 3 . Note that some values of irradiances in Table 3 are different from the values in Figures 21 to 26 due to curve-fitting method used for getting smooth line in Figure 27.

A practical test is performed using the $G-I$ curves in Figures 27 and 28 with the aid of a pyrheliometer (Soly2 model, Netherlands) at the same site and time. Different values of solar irradiance are tested by using the $G-I$ curve, and the results are compared with other values read by a pyrheliometer. The results are approximately the same, with a percentage error no more than $3.2 \%$. Hence, the solar model with the $G-I$ curve is easier to use to read the solar irradiance than using a pyrheliometer. The latter requires installation time and has a private structure, and it is widely used in fixed sites than moveable ones. The solar model is more reliable for measuring the solar irradiance for a fasttracked process.

Table $3 I_{\mathrm{sc}}$ and $V_{\text {oc }}$ values at different solar irradiance

\begin{tabular}{|c|c|c|}
\hline $\begin{array}{c}\text { Irradiance } \\
\boldsymbol{G}\left(\mathbf{W} / \mathbf{m}^{2}\right)\end{array}$ & $\begin{array}{c}\text { Short circuit } \\
\text { current, } \boldsymbol{I}_{\text {sc }}(\mathbf{A})\end{array}$ & $\begin{array}{c}\text { Open circuit } \\
\text { voltage, } \boldsymbol{V}_{\mathbf{~ o c}}(\mathbf{V})\end{array}$ \\
\hline 375.38 & 3.301 & 20.708 \\
\hline 497.55 & 4.14 & 21.053 \\
\hline 623.65 & 4.973 & 21.254 \\
\hline 810.72 & 6.502 & 21.247 \\
\hline 978.85 & 8.015 & 21.588 \\
\hline 1000.56 & 8.295 & 21.734 \\
\hline 1031.85 & 9.111 & 21.784 \\
\hline
\end{tabular}

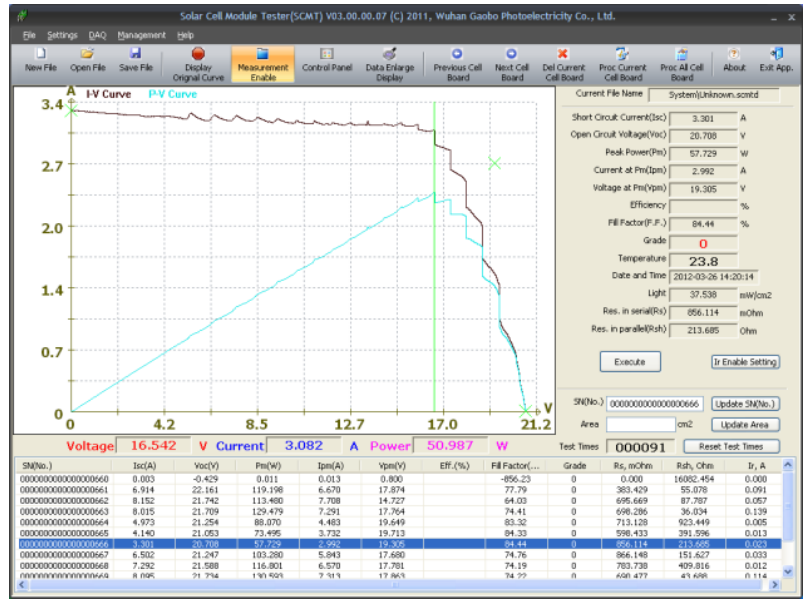

Fig. 20: $I-V$ and $P-V$ characteristic curves of the Solara PV model at $G$ $=373.38 \mathrm{~W} / \mathrm{m}^{2}$.

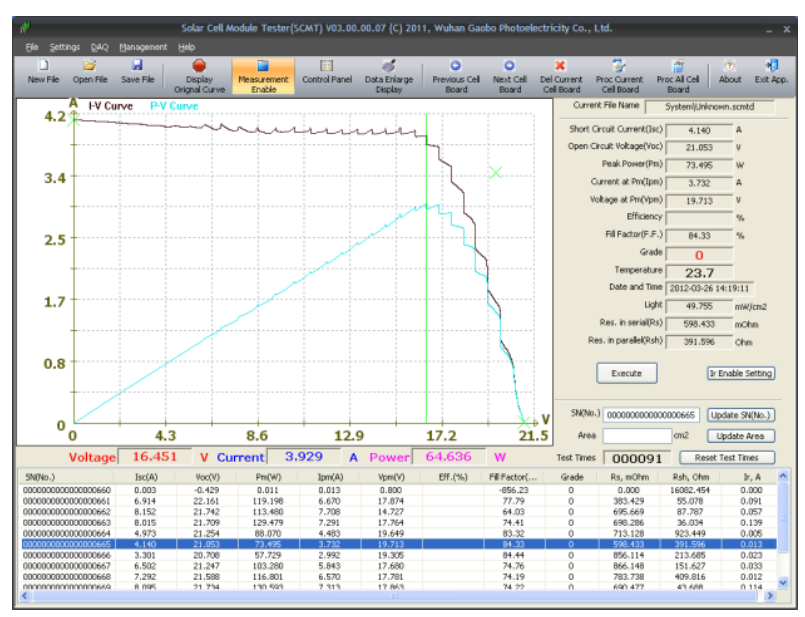

Fig. 21: $I-V$ and $P-V$ characteristic curves of the Solara PV model at $G$ $=497.55 \mathrm{~W} / \mathrm{m}^{2}$.

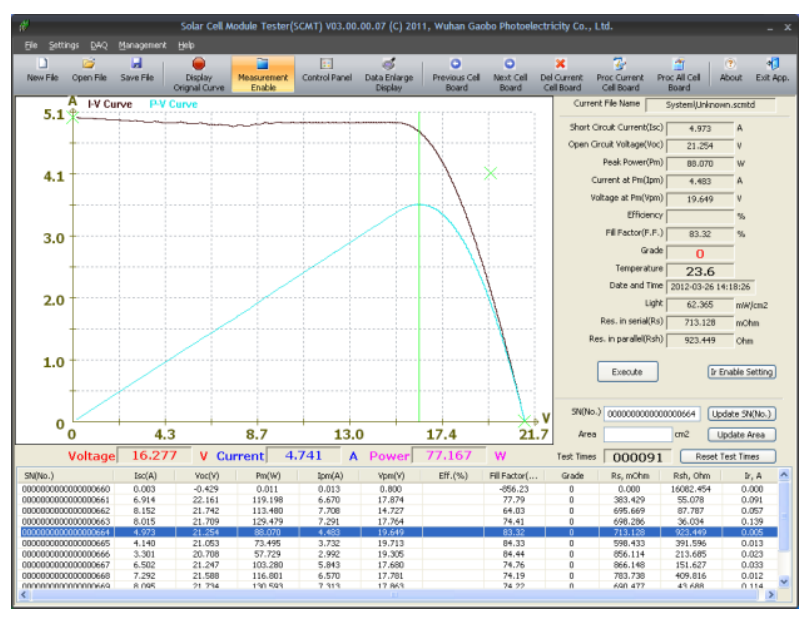

Fig. 22: $I-V$ and $P-V$ characteristic curves of the Solara PV model at $G$ $=623.65 \mathrm{~W} / \mathrm{m}^{2}$. 


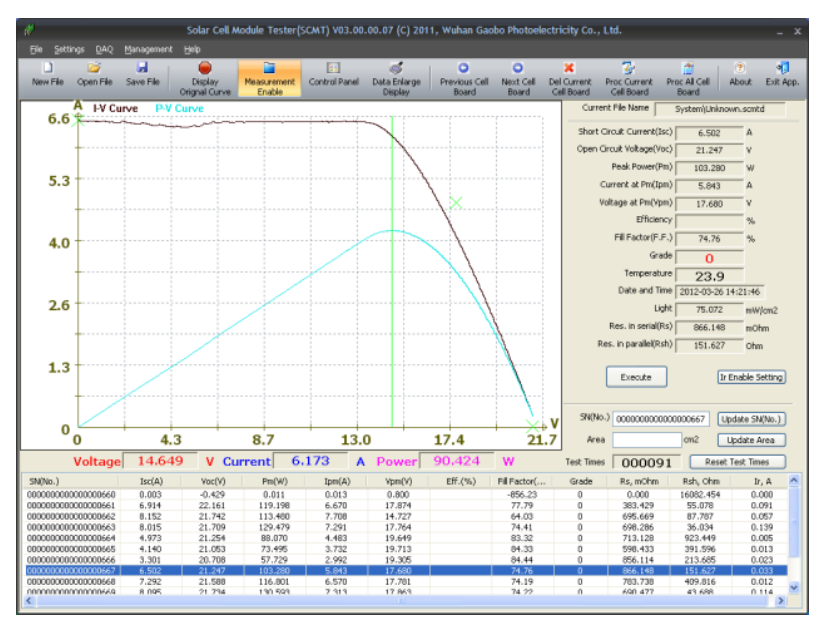

Fig. 23: $I-V$ and $P-V$ characteristic curves of the Solara PV model at $G$ $=750.72 \mathrm{~W} / \mathrm{m}^{2}$.

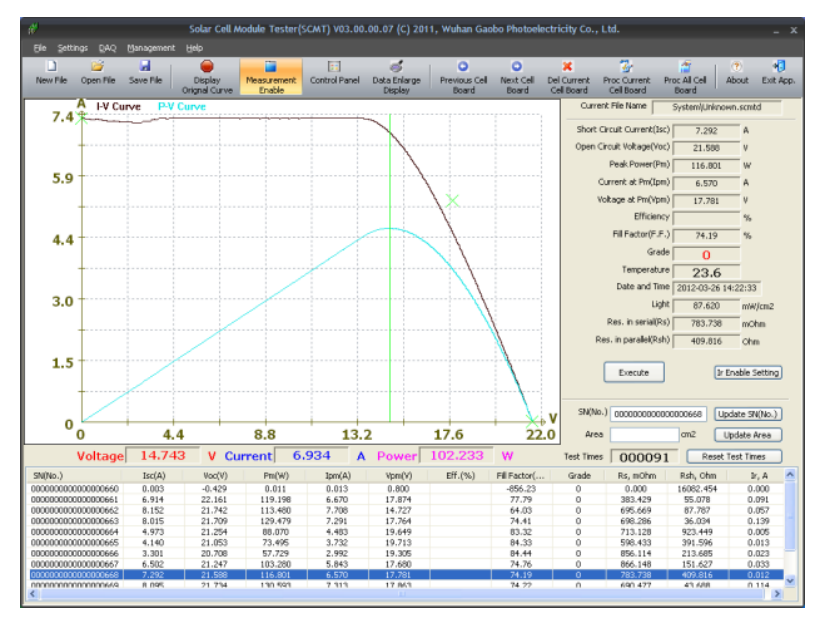

Fig. 24: $I-V$ and $P-V$ characteristic curves of the Solara PV model at $G$ $=876.2 \mathrm{~W} / \mathrm{m}^{2}$.

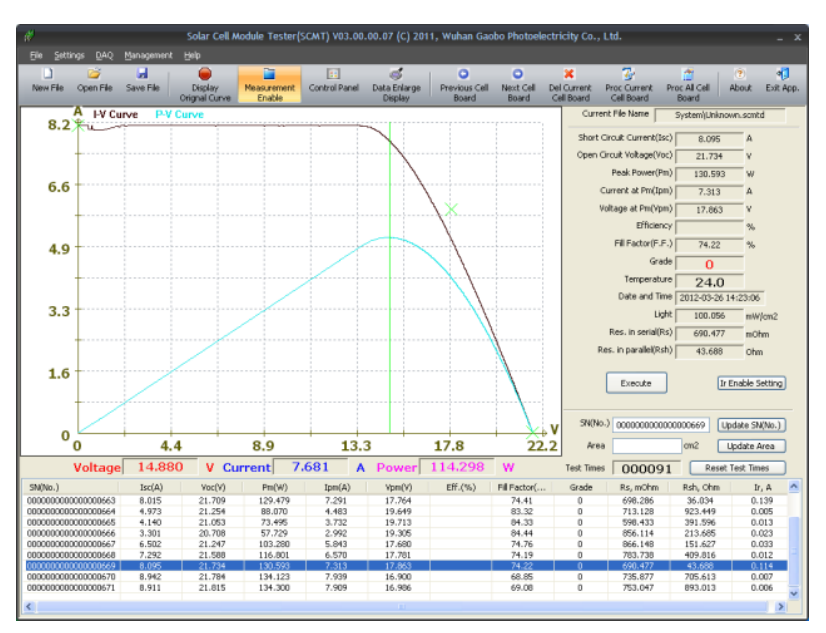

Fig. 25: $I-V$ and $P-V$ characteristic curves of the Solara PV model at $G$ $=1000.56 \mathrm{~W} / \mathrm{m}^{2}$.

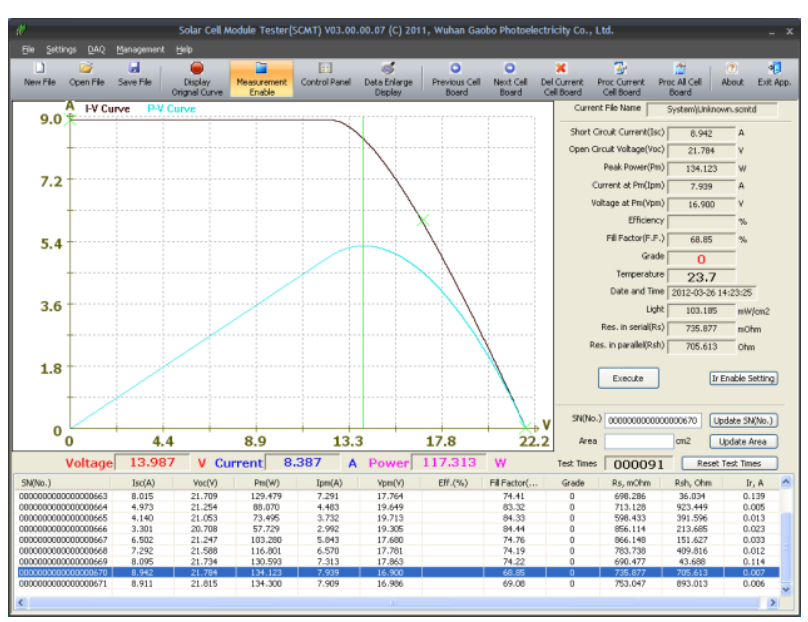

Fig. 26: $I-V$ and $P-V$ characteristic curves of the Solara PV model at $G$ $=1031.85 \mathrm{~W} / \mathrm{m}^{2}$.

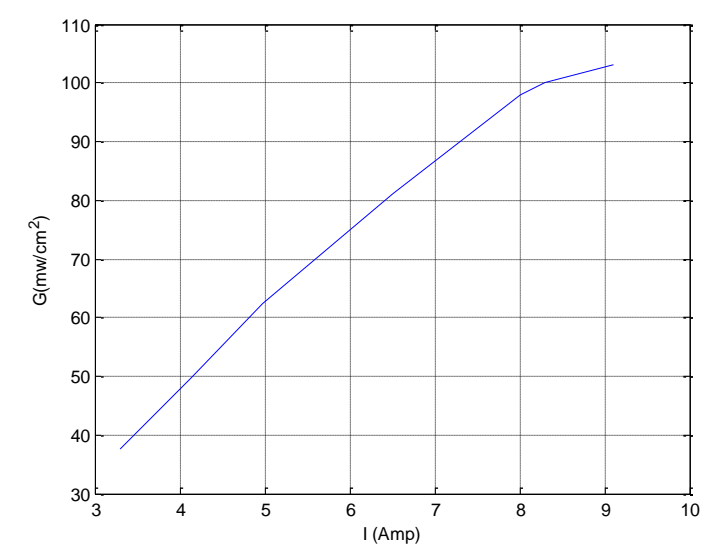

Fig. 27: $G-I$ curve for the Solara PV model (130 W, wide range of $G$ )

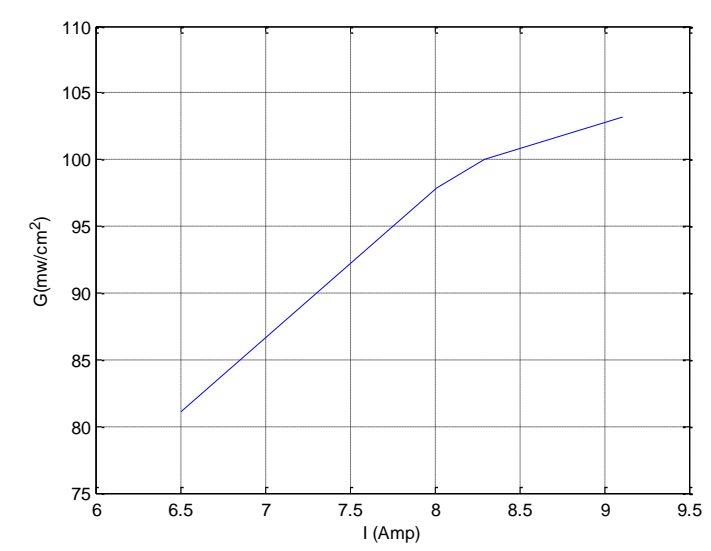

Fig. 28: $G-I$ curve for the Solara PV model ( $130 \mathrm{~W}$, small range of $G$ )

\section{Conclusions}

Different parameters can affect PV performance, such as solar irradiance, temperature, diode ideally factor, and series resistance. The effect of these parameters on the $\mathrm{O} / \mathrm{P}$ power of solar modules is evaluated, and the extracted results approximately match the existing parameters at the nameplate of each tested model. The 
PV models are tested theoretically (using a simulation model by Matlab software) and practically (using a solar model tester), and the following conclusions are drawn:

- As the cell temperature, series resistance, and diode ideality factor increase, the $\mathrm{O} / \mathrm{P}$ power of the $\mathrm{PV}$ model decreases. As the cell solar irradiance decreases, the O/P power of the PV model decreases.

- The solar model tester is more suitable than a diode equivalent circuit model for calculating the PV model parameters.

- The approximate value of solar irradiance can be calculated using the $G-I$ curve without using a pyrheliometer.

About 9\% error is incurred using the simulated model at standard solar irradiance. The error is zero when the solar model simulator is used.

\section{References}

[1] Solarbuzz, "Fast Solar Energy Facts: Global Performance" Internet Survey, URL: http://www.solarbuzz.com/FastFactsIndustry. htm.

[2] Solar Energy Industries Association, "The Solar Photovoltaic Industry in 2006" Internet Survey, URL:http://ap.stop.dupont.com/Photovoltaics/en_U S/assets/downloads/pdf/SEIA_StateofSolarIndustry 2006.pdf

[3] "Solar Energy" The Energy Report, May 2008, Internet Survey, URL:http://www.window.state.tx. us/specialrpt/energy/pdf/10-Solar Energy .pdf.

[4] David L. King, Jay A. Kratochvil, and William E. Boyson, "Measuring Solar Spectral and Angle-ofIncidence Effects on Photovoltaic Modules and Solar Irradiance Sensors", 26th PVSC; pp. 11131116, Sept. 30-0ct. 3, 1997.

[5] Junsetsu Tamura, "A New Method of Calculating In-Plane Irradiation By One-Minute Local Solar Irradiance", 3rd World Conference on Photovoltaic Energy Conversion, pp.2265-2268, 11-18 May, 2003.

[6] Mohammed Qassim Taha, Qusay Hatem Eesee, Salih Mohammed Salih, "Mathematical Modeling of different Photovoltaic Modules ", Journal of Telecommunications, Vol. 11, Issue 2, pp.59-64, Dec.-2011.

[7] Francisco M. González-Longatt, "Model of Photovoltaic Module in Matlab", 2DO Congreso Iberoamericano De Estuiantes De Ingenieria A Electrica, Electronica Y Computacion (II CIBELEC 2005).

[8] G.R. Walker, "Evaluating MPPT Topologies Using a Matlab PV model", Journal of Electrical \& Electronics Engineering, Vol. 21, No. 1, pp. 49-56, 2001.
[9] Geoff Walker. "Evaluating MPPT Converter Topologies Using Matlab PV Model", Department of Computer Science and Electrical Engineering, University of Queensland, Visited $10^{\text {th }}$ of April2012, Internet Survey URL: http://itee.uq.edu.au/ aupec/aupec00/walker00 .pdf

[10] W. Liu, "Diode Ideality Factor for Surface Recombination Current in AlGaAs/GaAs Hetero Junction Bipolar Transistors," IEEE Transactions on Electron Devices, vol. 39, pp. 2726-2732, 1992.

[11] PV Technology "Photovoltaic: Sustainable Power for the World." 08 Oct. 2005. Internet Survey, URL:http://digitalcommons.calpoly.edu/cgi/viewco ntent.cgi article $=1576 \&$ context $=$ theses

[12] A. Cheknane , S. Bensmain , B. Benyoucef, J.-P. Charles, and R. Zerdoum." Series Resistance of $\mathrm{SnO} 2 / \mathrm{SiO} 2 / \mathrm{Si}(\mathrm{n})$ Solar Cells" Internet Survey, URL: Visited on 25th of November-2011. http://www.icrepq.com/PONENCIAS/4.311.CHEK NANE.pdf

Salih Mohammed Salih: (Member IEEE) received the B.Sc. degree in Electrical Department from the University of Baghdad (1999)-Iraq, M.Sc. and Ph.D. degrees in electronic and communication engineering from the university of technology-Iraq in 2003 and 2008 respectively, part of his Ph.D. was completed at the national technical university of Athens from (scholarship-data collection, 2006-2007). Since 2005, he has been working with the University of Anbar-Iraq, where he is a lecturer in electrical engineering department. His research interests include modulation techniques, security, wireless communication, radar, computer networks, solar cell technology, and renewable energy resources. He published more than 30 papers in local and international journals and conferences. 